\title{
Dampak Pemekaran Desa Terhadap Tingkat Kesejahteraan Masyarakat di Desa Onemanu Kecamatan Lambandia Kabupaten Kolaka Timur
}

\author{
Nuraeni ${ }^{1}$; Nasir ${ }^{2}$; Asriani $^{3}$ \\ ${ }^{123}$ Universitas Halu Oleo, nurainhy11@gmail.com
}

\begin{abstract}
Abstrak
Penelitian ini menggunakan metode penelitian kualitatif, dengan penekanan pada deskriptif dan analisis. Penelitian ini dilaksanakan di Desa Onemanu Kecamatan Lambandia Kabupaten Kolaka Timur. Informan dalam penelitian ini berjumlah 6 orang. Teknik pengumpulan data terdiri dari penelitian kepustakaan, dan penelitian lapangan menggunakan teknik observasi, wawancara dan dokumentasi. Teknik analisis data bersifat deskriptif kualitatif. Hasil penelitian menunjukkan bahwa, setelah pemekaran desa cukup memberikan dampak positif terhadap kesejahteraan masyarakat di Desa Onemanu Kecamatan Lambandia Kabupaten Kolaka Timur. Dampak dari pemekaran desa ini dapat dilihat dari jumlah ketersediaan sarana pendapatan, pendidikan, kesehatan dan infrastruktur jalan yang cukup meningkat dari tahun sebelum pemekaran dan sesudah pemekaran. Pada tingkat pendapatan masyarakat menunjukkan hasil yang meningkat yakni memiliki pendapatan tambahan setiap bulannya jika di bandingkan dengan sebelum adanya pemekaran. Selain itu, pemekaran desa juga meningkatkan sarana pemerintahan Kantor Desa dalam meningkatkan pendapatan masyarakat. Dimana sarana pemerintahan tersebut baru di bangun setelah Desa Onemanu mekar dari Desa Mokupa.
\end{abstract}

Kata kunci : Dampak, Desa, Pemekaran, Kesejahteraan.

\begin{abstract}
The purpose of this study was to determine the impact of the expansion of the village on the welfare level of the community in Onemanu Village, Lambandia District, East Kolaka Regency. This study uses qualitative research methods, with emphasis on descriptive and analysis. This research was conducted in Onemanu Village, Lambandia District, East Kolaka Regency. Informants in this study amounted to 6 people. Data collection techniques consist of library research, and field research using observation, interview and documentation techniques. The data analysis technique is descriptive qualitative. The results of the study showed that, after the division of the village, it had a positive impact on the welfare of the community in Onemanu Village, Lambandia District, East Kolaka Regency. The impact of the expansion of the village can be seen from the increasing availability of means of income, education, health and road infrastructure from the year before pemekaran and after pemekaran. At the income level, the community shows an increasing result, namely having additional income each month when compared to before the expansion. In addition, the expansion of the village also increased the Village Office's government facilities in increasing community income. Where the government facilities were only built after Onemanu Village bloomed from Mokupa Village.
\end{abstract}

Keywords : Impact, Village, Expansion, Welfare 


\section{Pendahuluan}

Pemekaran daerah adalah salah satu bentuk pembentukan daerah dengan cara memecahkan satu kecamatan menjadi menjadi beberapa kecamatan yang sesuai dengan ketentuan dan syarat yang harus dipenuhi untuk melakukan pemekaran kecamatan. Pemekaran daerah sabagaimana dimaksud dalam Pasal 32 ayat (1) Undang-Undang Nomor 23 tahun 2014 tentang Pemerintah daerah, bahwa pemekaran daerah berupa pemecahan daerah Provinsi atau daerah kabupaten/kota untuk menjadi dua atau lebih daerah baru atau penggabungan bagian daerah dari daerah yang bersanding dalam satu daerah provinsi menjadi satu daerah baru. Pasal 32 ayat (2) mengatur pemekaran daerah dilakukan melalui tahapan daerah persiapan provinsi atau daerah persiapan kabupaten/kota. Undang-Undang Nomor 23 Tahun 2014 Pasal 32 ayat (3), bahwa pembentukan daerah persiapan harus memenuhi persyaratan dasar dan persyaratan administratif.

Pemekaran desa pada hakekatnya adalah upaya menciptakan pemerintahan yang lebih efektif dan efisien serta berdaya guna demi mewujudkan percepatan peningkatan kesejahtraan masyarakat. Dengan demikian pembangunan dan pengembangan otonomi dalam masa transisi ini adalah mengembangan prakasa dari dalam, menumbuhkan kekuatan-kekuatan baru dari masyarakat, sehingga intervensi dari luar termasuk dari pemerintah terhadap masyarakat harus merupakan proses pemberdayaan dalam rangka mengelola pembangunan untuk mengantisipasi perubahan dan peluang yang lebih luas. Secara esensial sebenarnya dalam menyelenggaraan desentralisasi terdapat dua elemen penting yang sangat penting yang saling berkaitan yaitu pembentukan daerah otonom dan penyerahan kekuasaan secara hukum dari pemerintah pusat ke pemerintah daerah untuk mengatur dan menangani urusan pemerintah tertentu yang diserahkan.

Desa Onemanu adalah salah satu desa di Kecamatan Lambandia Kabupaten Kolaka Timur yang pada awalnya merupakan Desa Mokupa Kecamatan Lambandia dan saat itu masih Kabupaten Kolaka. Desa Onemanu di mekarkan dari dari Desa Mokupa karena seakan-akan pada saat itu Desa Onemanu terpisahkan dari Desa Mokupa, seperti pada pembangunan tidak ada yang menyentuh Desa Onemanu. Desa Onemanu di mekarkan pada tahun 2012. Di Desa Onemanu terbagi 
menjadi 4 dusun. Dengan luas wilayah $\pm 14 \mathrm{Km} 2$ Sedangkan jarak dari Desa Onemanu ke ibu kota kecamatan yaitu $9 \mathrm{Km}$ kearah utara.

Sebelum melakukan pemekaran, Desa Onemanu merupakan salah satu dusun dari Desa Mokupa. Namun selama bergabung, potensi-potensi yang ada di Onemanu belum di manfaatkan dengan baik oleh pemerintah dengan pemberian program yang baik. Selain itu pula lokasi Desa Oneamanu tidak tersentuh oleh pembangunan sehingga dengan dasar inilah pengurus Desa Onemanu menyampaikan aspirasinya untuk melakukan pemekaran dari Desa Mokupa.

Pemekaran Desa Onemanu ini merupakan bukanlah inisiatif oleh para warga masyarakat, karena warga masyarakat saat itu takut jika ingin di pisahkan dari desa sebelumnya mereka takut jika pembangunan tidak akan lagi menyentuh desa mereka, karena saat masih bergabung dengan Desa Mokupa, desa tersebut tidak tersentuh oleh pembangunan bagaimana jika berpisah, inilah yang di takutkan masyarakat. Sehingga inisiatif ini dari pengurus perangkat Desa Mokupa dan perangkat Desa Onemanu yang sebelumnya masih merupakan dusun dari Desa Mokupa yang merupakan desa induk sebelum pemekaran ini menyetujui tentang adanya kebijakan pemekaran desa. Seluruh pemangku kepentingan menganggap kurang diperhatikannya kualitas pelayanan kepada masyarakat dusun termasuk pembangunan infrastruktur yang sangat minim serta pelayanan publik yang sangat sulit untuk di jangkau.

Inti dari pemekaran yang dilakukan di Desa Onemanu adalah untuk meningkatkan dan mendekatkan pelayanan pemerintah kepada masyarakat. Serta memberikan andil besar terhadap percepatan pembangunan masyarakat seperti pembangunan infrastruktur, peningkatan potensi wilayah, peningkatan keikutsertaan masyarakat dalam pembangunan di Desa Onemanu.

Setelah melakukan pemekaran di tahun 2012, Desa Onemanu sudah tersentuh oleh pembangunan, mulai dari Pembangunan di bidang pendidikan sekolah yang semakin meningkat. Indikator yang dapat mengukur tingkat perkembangan pembangunan pendidikan di Desa Onemanu seperti meningkatnya sekolah dan guru. Sehingga masyarakat Onemanu mudah untuk menyekolahkan anaknya dengan jarak yang mudah di jangkau serta anak-anak di Desa Onemanu 
tidak terhambat lagi untuk melanjutkan pendidikannya terutama SD/TK. Begitupun dengan meningkatnya guru yang dapat memudahkan guru untuk mengambil keahliannya masing-masing dalam setiap bidang. Selain itu pembangunan pendidikan tempat belajar qur-an dan bidang pertanian juga semakin meningkat, yang dimana pasca pemekaran Desa Onemanu terbentuknya pendidikan untuk para petani dalam melakukan pembelajaran agar lebih meningkatkan kualitas dalam pertaniannya terutama bagi para petani pemula, yang di laksanakan setiap hari ju'mat. Dengan adanya pembangunan pendidikan untuk para petani sangat bermanfaat kepada warga/masyarakat sehingga dengan ini dapat menigkatkan kesejahteraan bagi masyarakat.

Begitu pula dengan pembangunan kesehatan yang semakin meningkat, yang pada awalnya sebelum mengalami pemekaran masyarakat Onemanu harus mengakses jalan yang cukup jauh untuk memeriksa kesehatan, tepatnya di Desa Mokupa yang merupakan Desa induk sebelum pemekaran. Namun pasca pemekaran Desa Onemanu sudah memiliki bangunan Pos Kesehatan Desa sendiri, sehingga masyarakat Onemanu mudah untuk memeriksa kesehatan dengan baik dan mudah untuk di jangkau.

Selain itu pembangunan infrastruktur jalan yang semakin meningkat yang pada awalnya sebelum mengalami pemekaran, jembatan yang ada di poros ataupun jembatan kebun yang ada di Desa Onemanu masih menggunakan batang kelapa yang di jejerkan sehingga banyak pengendara yang sangat sulit untuk melalui jembatan tersebut selain itu sering juga pengendara terjatuh akibat jembatan yang sangat sulit untuk dilalui. Namun setelah pemekaran adanya anggaran dana desa yang masuk di Desa Onemanu, sehingga masalah jembatan sekarang sudah teratasi, seperti yang kita lihat bahwa jembatan yang ada di Desa Onemanu seperti jembatanjembatan yang pada umumnya terbuat dari semen, baik jembatan poros ataupun jembatan menuju kebun. Selain itu pembangunan dueker plat yang awalnya masih terbuat dari papan-papan yang disusun untuk di jadikan sarana transportasi namun setelah adanya pemekaran desa telah dibangunnya dueker plat sehingga dengan itu lebih memudahkan masyarakat dalam mengakses jalan tersebut, begitupun dengan jalan poros/jalan setapak kebun Desa Onemanu sangat sulit untuk di akses. Namun 
sejak Desa Onemanu telah mengalami pemekaran, jalan poros/jalan setapak kebun sudah mulai membaik walaupun belum pengaspalan namun sudah mulai pengerasan jalan. Dengan adanya pemekaran Desa Onemanu sangat berpengaruh bagi warga/masyarakat yang ada di Desa Onemanu untuk mengakses jalan, baik untuk keperluan pribadi ataupun keperluan bersama.

Adapun pembangunan lainnya yang sangat berpengaruh dengan aspek ekonomi masyarakat yaitu pemanfaat potensi wilayah yang dapat meningkatkan perekonomian masyarakat. Contohnya, pembangunan wisata di Desa Onemanu yang dapat meningkatkan perekonomian warga/masyarakat karena dengan adanya wisata tersebut, warga/masyarakat dapat membuka warung makan ataupun menjual minuman untuk para pengunjung wisata tersebut. Dengan itu Desa Onemanu dapat lebih meningkatan perekonomian masyarakat. Hal ini mendorong penulis untuk mengkaji dan meneliti "Dampak Pemekaran Desa Terhadap Tingkat Kesejahteraan Masyarakat di Desa Onemanu Kecamatan Lambandia Kabupaten Kolaka Timur”. tujuan dari penelitian ini adalah untuk mengetahui "Dampak Pemekaran Desa Terhadap Tingkat Kesejahteraan Masyarakat di Desa Onemanu Kecamatan Lambandia Kabupaten Kolaka Timur.

\section{Metode}

Jenis penelitian yang digunakan adalah penelitian deskriptif dengan pendekatan penelitian kualitatif. Menurut (Zuriah, 2006) penelitian deskriptif adalah penelitian yang di arahkan untuk memberi gejala-gejala, fakta-fakta, atau kejadian -kejadian secara sistematis dan akurat, mengenai sifat-sifat populasi atau daerah tertentu. Tempat pelaksanaan penelitian ini akan dilakukan di Desa Onemanu Kecamatan Lambandia Kabupaten Kolaka Timur. Pemilihan lokasi ini didasarkan pertimbangan bagi peneliti bahwa adanya "Dampak pemekaran desa terhadap tingkat kesejahteraan masyarakat di Desa Onemanu Kecamatan Lambandia Kabupaten Kolaka Timur”. Subjek dalam penelitian ini adalah seluruh kepala keluarga di Desa Onemanu yang terdiri dari 4 dusun. Dusun I Mario rennu 53 KK, Dusun II Polengan 86 KK, Dusun III Onemanu 46 KK, Dusun IV Tenri pakku 38 KK, Jumlah keseluruhan kepala keluarga di Desa Onemanu 223 KK. 
Teknik pengumpulan data merupakan usaha untuk mengumpulkan bahan-bahan yang berhubungan dengan penelitian yang dapat berupa data, fakta, gejala maupun informasi yang stafnya falid (sebenarnya), realible (dapat di percaya), dan obyektif (sesuai dengan kenyataan). Teknik pengumpulan data yang digunakan dalam penelitian ini adalah studi kepustakaan, dan Studi lapangan. Adapun teknik perolehan datanya melalui observasi ,wawancara (interview), dokumentasi yaitu teknik pengumpulan data dengan cara mengumpulkan, dan mencatat data-data yang berkaitan dengan penelitian. Teknik analisis yang dilaksanakan dalam penelitian ini analisis deskriptif kualitatif. Data yang telah di peroleh dilokasi baik yang bersifat data primer maupun data sekunder kemudian diolah dan ditabulasi berdasarkan sifat dan jenisnya, selanjutnya di interpretasi secara deskriptif untuk menjawab rumusan masalah. Menurut Miles dan Huberman dalam (Sugiyono 2015) aktivitas dalam analisis data kualitatif dilakukan secara terus menerus sampai tuntas, sehingga datanya sudah jenuh

\section{Hasil dan Pembahasan}

Ketersediaan sarana sangat mempengaruhi tingkat kesejahteraan masayarakat, bahkan ketersediaan sarana tersebut menjadi salah satu indikator atau tolak ukur dari kesejahteraan masyarakat yang mendiami daerah tertentu. Selain itu pula, faktor yang turut mempengaruhi dampak suatu wilayah dimekarkan adalah faktor pendapatan, pendidikan, kesehatan dan infrastruktur.

Tabel 1. Sarana dan Parsarana Kantor Desa Onemanu

\begin{tabular}{|l|l|l|}
\hline No & Jenis Sarana & Jumlah \\
\hline 1 & Kantor Desa & 1 Unit \\
\hline 2 & Poskesdes (Pos Kesehatan Desa) & 1 Unit \\
\hline 3 & Sekolah SD & 1 Unit \\
\hline 4 & Sekolah TK & 1 Unit \\
\hline 5 & Jembatan & 5 Unit \\
\hline 6 & Dueker Plat & 20 Unit \\
\hline 7 & Tempat Wisata & 1 Unit \\
\hline Jumlah & & 30 Unit \\
\hline
\end{tabular}

Sumber : Kantor Desa Onemanu, Tahun 2019 


\section{Dampak Pemekaran Desa Terhadap Tingkat Kesejahteraan Masyarakat di Desa Onemanu Kecamatan Lambandia Kabupaten Kolaka Timur}

Dari hasil observasi dan wawancara penulis dilapangan, penulis menemukan bahwa dari aspek pemekaran desa terhadap tingkat kesejahteraan masyarakat di Desa Onemanu menunjukkan suatu kesejahteraan masyarakat yang baik, hal ini dapat dilihat dari indikator ketersediaan sarana pendapatan, pendidikan, kesehatan dan infrastruktur yang meningkat.

\section{Dampak Positif}

\section{a. Pendapatan}

Meningkatkan pendapatan merupakan cita-cita oleh setiap orang dalam hal ini untuk dapat memenuhi kebutuhan sehari-hari. Dengan adanya pemekaran diharapkan pemerintah dapat membuka lapangan kerja dengan tujuan mensejahterakan masyarakatnya. Artinya dengan adanya pemekaran Desa Onemanu telah terbentuknya lapangan kerja yaitu dengan memanfaatkannya potensi wilayah yang ada di Desa Onemanu dengan membangun suatu tempat wisata tersebut. Dengan adanya tempat wisata yang dibangun setelah pemekaran desa, sangatlah bermanfaat bagi desa dan masyarakatnya untuk lebih meningkatkan pendapatan bagi masyarakat.

\section{b. Pendidikan}

Pendidikan di Desa Onemanu di titikberatkan pada peningkatan mutu dan perluasan wajib belajar di semua jenjang pendidikan, yaitu mulai dari TK sampai dengan Sekolah Lanjut Atas (SLTA). Salah satu indikator kesejahteraan masyarakat adalah dilihat dari aspek pendidikan yang mereka miliki, sebab dengan faktor pendidikan ini dapat menentukan setiap tindakannya terutama dalam mengelolah setiap kegiatan usaha, misalnya cepat menerima informasi pada berbagai sektor kegiatan usaha yang berasal dari berbagai sumber informasi, baik melalui cetak ataupun media elektronik. Tingkat pendidikan yang cukup memadai dapat menentukan status sosial seseorang dalam lingkungan masyarakat. Selain itu tingkat pendidikan menggambarkan derajat kemampuan yang dimiliki seseorang, tingkat pendidikan juga menjadi landasan untuk menentukan pilihan masa depan 
selanjutnya, baik pekerjaan maupun keterlibatannya dalam kegiatan pembangunan dan kemasyarakatan.

Sebelum pemekaran Desa Onemanu, pembangunan pendidikan yang ada di desa boleh dikatakan masih terbatas, karena pembangunan pendidikan diperioritaskan di ibu kota desa, sehingga pembangunan pendidikan dusun-dusun lain menjadi terhambat. Namun setelah adanya pemekaran desa pembangunan pendidikan sudah berkembang dengan baik misalnya pembangunan tingkat pendidikan yang sebelumnya masih kurang layak untuk digunakan sekarang sudah sangat baik digunakan dalam melaksanakan setiap aktivitas pendidikan tersebut.

\section{c. Kesehatan}

Pembangunan kesehatan di Desa Onemanu dititikberatkan pada peningkatan mutu pelayanan kesehatan masyarakatdan terwujudnya keluarga bahagia dan sejahtera, dengan melihat dari tingkat kesejahteraan penduduk suatu daerah atau Negara. Semakin baik tingkat kesehatan seseorang maka, hal ini cenderung akan lebih meningkatkan produktivitas seseorang yang pada akhirnya akan meningkatkan pendapatan dan kesejahteraannya.

\section{d. Infrastruktur Jalan}

Infrastruktur jalan merupakan salah satu sarana angkutan darat yang penting untuk memperlancar roda kegiatan ekonomi dan meningkatkan kesejahteraan masyarakat. Dengan semakin meningkatnya usaha pembangunan dibidang sarana dan prasarana akan menuntun peningkatkan pembangunan seperti jalan guna memperlancar lalu lintas barang dan jasa dari satu desa ke desa lainnya. Sarana infrastruktur jalan di Desa Onemanu sebelum pemekaran tahun 2012 dan setelah pemekaran tahun 2012 yang merupakan jalan desa.

Infrastruktur jalan merupakan salah satu indikator untuk mengukur kesejahteraan masyarakat. Setelah adanya pemekaran di Desa Onemanu pembangunan infrastruktur jalan semakin meningkat, mulai dari sarana jalan raya ataupun sarana jalan setapak. Sehingga lebih memudahkan masyarakat desa dalam mengakses jalan yang digunakan sebagai transportasi untuk menghubungkan dengan desa satu ke desa lainnya, juga untuk mendukung aktivitas masyarakat desa terutama dalam bidang ekonomi, sosial dan budaya. Karena jalan dapat dikatakan 
sebagai akses penting untuk menentukan kesejahteraan masyarakat, sebab apabila sarana jalan yang tidak memadai maka menyebabkan kegiatan transportasi masyarakat terhambat.

\section{Dampak Negatif}

Beberapa dampak negatif yang muncul setelah pemekeran di Desa Onemanu Kecamatan Lambandia Kabupaten Kolaka Timur, yang diantaranya:

\section{a. Konflik dalam pemilihan Kepala Desa}

Setelah adanya pemekaran di Desa Onemanu, dengan adanya pemilihan Kepala Desa secara serentak, beberapa konflik yang muncul pada masyarakat. Sehingga menyebabkan perselisihan antara warga masyarakat yang ada di Desa Onemanu tersebut.

Berdasarkan hasil observasi penulis sekaligus warga di Desa Onemanu, menyatakan bahwa benar setelah pemilihan kepala desa di Desa Onemanu secara serentak, terjadinya konflik antara warga satu dengan warga lainnya yang ada di Desa Onemanu itu sendiri.

\section{b. Kurangnya Pelatihan Dan Pengembangan Skill Masyarakat Petani Kakao Yang Menyebabkan Kurang Produktifnya Tanaman Kakao.}

Tanaman kakao merupakan sumber mata pencaharian masyarakat di Desa Onemanu utamanya para petani. Seperti yang kita ketahui bahwa setelah adanya pemekaran di Desa Onemanu dan adanya pembangunan pendidikan di bidang pertanian, sangat memberikan dampak positif bagi masyarakat, khususnya para petani. Namun, kurangnya pelatihan untuk mengembangkan skill masyarakat dalam pertanian, khususnya dalam meningkatkan tanaman kakao yang saat ini tidak produkf lagi, sehingga dapat menyebabkan tingkat pendapatan petani kakao semakin menurun.

\section{Kesimpulan}

Berdasarkan hasil uraian wawancara dan hasil observasi penelitian yang dilakukan oleh penulis. Bahwa peningkatan kesejahteraan masyarakat cukup memberikan dampak posistif bagi perkembangan Desa Onemanu. dapat dilihat dari segi Pendapatan yang semakin meningkat setelah adanya pemekaran, serta tingkat 
pendidikan yang semakin membaik dengan adanya kelengkapan sarana dan prasarana setelah pemekaran. Selain itu tingkat kesehatan menunjukkan peningkatan yang baik, dimana telah berdiri satu unit Pos Kesehatan Desa setelah pemekaran, sedangkan Infrastruktur jalan juga semakin meningkat setelah adanya pemekaran di Desa Onemanu.

Selain itu, juga adanya dampak negatif yang muncul setelah pemekaran di Desa Onemanu yaitu terjadinya konflik antar warga masyarakat yang ada di Desa Onemanu dalam pemilihan kepala desa secara serentak. Serta, kurangnya pelatiha dan pengembangan skill petani kakao yang dapat menyebabkan menurunnya tingkat pendapatan para petani kakao.

\section{Referensi}

Chalid, Nursiah dan Yusuf, Yusbar. (2014). Pengaruh Tingkat Kemiskinan, Tingkat Pengangguran, Upah Minimum Kabupaten/Kota Dan Laju Pertumbuhan Ekonomi Terhadap Indeks Pembangunan Manusia di Provinsi RiauJurnal Ekonomi, 22(2), 1-12. Retrieved From E-Journal Riau University. .

Makagansa, H.R (2008). Tantangan Pemekaran Daerah . Fuspad: Sleman

RPJM Desa Onemanu (2017-2023).

Sugiyono. (2015). Metode Penelitian Pendidikan (Pendekatan Kuantitatif, Kualitatif R\&D). Penerbit CV. Alfabeta:Bandung.

Zuhro, R.Siti, Dkk. (2009). Demokrasi Lokal (Perubahan Dan Kesinambungan Nilai-Nilai Budaya Politik Lokal Di

Zuriah, Nurul. (2006). Metedologi Penelitian Sosial Dan Pendidikan Teori-Apikasi. Jakarta: Bumi Aksara

Undang-Undang No 23 Tahun 2014 tentang Pemerintahan Daerah.

Peraturan Pemerintah No 78 Tahun 2007 tentang pemekaran daerah/wilayah. 